May 2019

\title{
Rethinking the problem of faculty resistance to engaging with students as partners in learning and teaching in higher education
}

Kelly E. Matthews

The University of Queensland, k.matthews1@uq.edu.au

Follow this and additional works at: https://digitalcommons.georgiasouthern.edu/ij-sotl

\section{Recommended Citation}

Matthews, Kelly E. (2019) "Rethinking the problem of faculty resistance to engaging with students as partners in learning and teaching in higher education," International Journal for the Scholarship of Teaching and Learning: Vol. 13: No. 2, Article 2.

Available at: https://doi.org/10.20429/ijsotl.2019.130202 


\title{
Rethinking the problem of faculty resistance to engaging with students as partners in learning and teaching in higher education
}

\author{
Abstract \\ Engaging students as partners in the scholarship of learning and teaching (SoTL) is a principle guiding \\ good practice. Enthusiasm for student-faculty partnerships in learning and teaching continues to grow. In \\ this essay, I want to invite readers to reflect with me about concerns of resistance to partnership \\ practices. I interweave stories from my experiences with selected literature that is shifting the \\ conversation about the 'challenge of resistance' in partnership work in learning and teaching. Positioning \\ students as partners work as a values-based practice and in the context of 'scaling-up' partnership \\ programs, I argue that our pre-occupation with resistance is problematic. Instead, we should accept \\ resistance as part of a natural sense-making process that allows us to think together about the \\ complexity of genuine pedagogical partnership.
}

\section{Keywords}

Students as partners, SoTL, resistance, scaling-up, pedagogical partnerships

\section{Creative Commons License}

(c) (i) $\ominus$

This work is licensed under a Creative Commons Attribution-Noncommercial-No Derivative Works 4.0 License.

\section{Cover Page Footnote}

Thanks Mick Healey, Ruth Healey and Sarah Rasmussen for offering their insights on this piece as critical friends. 
IJ-SoTL, Vol. 13 [2019], N0. 2, Art. 2

\title{
Rethinking the Problem of Faculty Resistance to Engaging with Students as Partners in Learning and Teaching in Higher Education
}

\author{
Kelly E. Matthews
}

The University of Queensland

\author{
Received 7 September 2018;Accepted 6 March 2019
}

\begin{abstract}
Engaging students as partners in the scholarship of learning and teaching (SoTL) is a principle guiding good practice. Enthusiasm for student-faculty partnerships in learning and teaching continues to grow. In this essay, I want to invite readers to reflect with me about concerns of resistance to partnership practices. I interweave stories from my experiences with selected literature that is shifting the conversation about the 'challenge of resistance' in partnership work in learning and teaching. Positioning students as partners work as a values-based practice and in the context of 'scaling-up' partnership programs, I argue that our pre-occupation with resistance is problematic. Instead, we should accept resistance as part of a natural sense-making process that allows us to think together about the complexity of genuine pedagogical partnership.
\end{abstract}

\section{INTRODUCTION}

The scholarship of learning and teaching (SoTL) movement embraces working with students in partnership as a matter of good practice in SoTL (Felten, 20I3; Werder, Pope-Ruark, \& Verwood, 20I6). As a member of the international SoTL community and through an Australian Learning and Teaching Fellowship, I have given a lot of time in the past five years to thinking, talking, researching, and writing about engaging with students as partners to shape higher education as well as engaging in partnership with undergraduate and post-graduate students. In practicing student-faculty partnership, we value dialogue across different perspectives and the uncertainty of co-creation while shifting our beliefs about student expertise. Many people, including myself, want to see more faculty (academics in the UK and Australia) and students engaging in transformative partnership practices.

And the enthusiasm for institutional-supported 'partnership programs' is growing. Translating, on a large-scale, the aspirations and ethos of engaging with students as partners in learning and teaching in higher education structures laden in power and hierarchy is a complicated task. Asking lots of questions regularly during this tricky theory-to-practice process is vital; hard, uncomfortable questions that often cannot be answered neatly. Luckily, in trying to answer these difficult yet must-ask questions, we can draw on the principles of partnership.

I regularly question my own practices and beliefs about engaging in student-faculty partnerships in teaching and learning. However, I have observed that sometimes questioning (by myself or others) of students as partners practices or ideas is not well met. This questioning can be perceived as resistance or obstruction threatening the 'scaling-up' of programs and practices that seek to engage students as partners. These concerns about resistance are a visible theme in the literature and in my own work facilitating workshops, conducting research on partnership practices, drafting institutional policy to envision large-scale partnership programs, and engaging in professional conversations about teaching and learning.

In this reflective essay I continue an ongoing conversation in our discourse community about resistance to students as partners practices. I argue that our pre-occupation with resistance is masking, perhaps enabling, a deeper and more fundamental issue that undermines the principles that define partnership and the aspirations of the students as partners movement - the issue of doing students as partners without enacting the values or principles of partnership inherent to students as partners praxis.

To this end, I share a few stories about how perceptions of resistance manifests into solutions that are antithetical to the partnership principles of mutual respect, reciprocity, and shared responsibility (principles espoused by Cook-Sather, Bovill, \& Felten, 20I4; Healey, Flint, \& Harrington, 20I4). In doing so, I interweave stories from my experience with selected literature, including some of my scholarship, to evidence the productive evolution of how resistance is framed within our discourse community. I conclude with a call to action that provokes us to challenge our own rhetoric about resistance and embrace the opportunity that resistance offers to embody the principles of partnership ourselves, instead of unwittingly playing into the appropriation of students as partners language that diminishes the ethos and aspirations to which our movement is committed.

\section{THE PROBLEM OF RESISTANCE}

Like many other scholars - Bovill (20I7) in the UK; Cates, Madigan, and Reitenauer (2018) in the USA; Cook-Sather and Felten (20I7) in the USA; Dwyer (20I8) in Australia; Healey and Healey (20I8) in the UK; Kehler,Verwood, and Smith (2017) in Canada; and Peters and Mathias (20I8) in the UK, I share a commitment to the principles and values underpinning partnership practices and advocate for engaging with students as partners in higher education in ways that challenge taken-for-granted assumptions (Matthews, 2017). Encouraging more people to embrace the work, and engaging in pedagogical and SoTL partnerships with students, are my ongoing sources of motivation.

As momentum builds internationally around the shared language of engaging with students as partners in learning and teaching (Matthews, Cook-Sather, \& Healey, 2018), I regularly have colleagues coming to workshops seeking support to answer the question: "How to get more faculty across disciplines and experience levels on board with this concept?" (pre-survey response from 2018 International Students as Partners Institute participant). Many universities are relying on educational developers in centralized or discipline-based teaching and learning units to assist faculty in innovative pedagogical work, including engaging with students as partners: "As an Ed Designer in my role I often find lecturers (faculty or instructors) have difficulty with the concept" (pre-survey response from 2016 Australian Students as Partners Roundtable participant). 
While I welcome the growing interest in practicing partnership in SoTL inquiry and as everyday pedagogical praxis, I find myself increasingly troubled by a focus on 'scaling-up' partnership that positions resistance to the work as a problem to be overcome.

Let me share one example to clarify.

Recently I partnered on research that explored conceptions of engaging students as partners with practitioners engaged in the work at an institutional level (Matthews, Dwyer, Hines, \& Turner, 2018) and institutional leaders with strategic oversight for partnership programs (Matthews, Dwyer, Russell, \& Enright, 20/8). Resistance - "disinclination and opposition among staff [faculty] to working with students collaboratively beyond the traditional teacher-student hierarchy" (Matthews, Dwyer, Hines, \& Turner, p. 8) - was loud in the interviews and directed at members of faculty (as opposed to professional or administrative staff).While some interviewees sought to understand why faculty might be resistant to engaging with students as partners in learning and teaching, other interviewees (both students and faculty/ staff) positioned resistors as out-of-date faculty members who were older, teachers not good at teaching, or people scared of change. The concern about resistance tended to be presented as a hypothetical problem when interviewees discussed 'scaling-up' partnership programs. In other words, a perceived resistance unfolding in the future when discussions would reach beyond 'the already converted'.

Some of the interview excerpts read as though 'students as partners' was a platform giving permission to shame people not engaging in partnership projects. I have presented workshops to hundreds of people about the ethos and practices associated with engaging students and faculty in partnerships for learning and teaching in higher education. The topic of resistance almost always arises as a challenge or obstacle. At a recent Australian Students as Partners Roundtable event, a colleague responsible for leading an institutional program shared a narrative that resonated with others in attendance:

\section{I recently tried to explain the concept of student partnership to an academic staff (faculty) member that I work with who had not heard of it before. After what I thought was a pretty clear and convincing introduction to students as partners, its princi- ples, and its benefits, the response I received was: "I find that hard to accept, it undermines the fact that as academics (faculty members) we are the experts in our fields and in teaching and research'. I'm sure for most people familiar with or engaged in partnership related work that we could endlessly advocate for the principles and values of students as partners in opposition to this viewpoint. Unfortunately, though, I think we would become exhausted if we attempted to challenge this perspective at every point that it appears. So, one question that I am left with is, what can we do to overcome resistance to student partnership? (Ernight, Matthews, Russell, \& Sherwood, 2018)}

This one story illuminates the commitment of partnership practitioners, advocates, and the increasing numbers of people employed to run such programs along with the frustration of having to convince colleagues to engage in the work. And this story is affirmed in the scholarly literature. Many of the top-cited papers in the field explicitly discuss the challenge of resistance, acknowledging the ubiquity of this theme amongst practitioners (Bovill et al, 20l6; Cook-Sather, Bovill, \& Felten, 20l4). As the empirical evidence continues to accumulate about the benefits of engaging in partnerships in learning and teaching for both students and staff (Matthews et al, 2018), it is unsurprising that advocates want to see more faculty members involved in partnership practices.

\section{REFRAMING THE PROBLEM OF RESISTANCE}

Framing resistance as questioning partnership, whether in practice or theory, is problematic because it implies that questioning is resistance. If we reframe our thinking, then a faculty member, as in the above narrative, questioning notions of who has expertise in matters of learning and teaching becomes an invitation to dialogue about complex and challenging ideas. This presents an opportunity for advocates of partnership to enact the principles of partnership by understanding someone else's standpoint while acknowledging that we are asking people to think very differently when we introduce the practice of 'student partnership' in learning and teaching. Instead of trying to convince faculty and worrying about resistance to our telling transaction, we should be engaging in dialogic interactions about the complexity of partnerships in learning and teaching.

Or in other words, to simply tell faculty that partnership is good and expect they do it without question or thought, undermines the messy complexity of genuine partnership praxis (Matthews et al, 2019). A recent study of an established institutional pedagogical partnership program in the USA argued for empathy and dialogue in the face of resistance that can actually work toward deeper pedagogical partnerships (Ntem \& CookSather, 2018). Thus, the conversations about resistance in students as partners literature are evolving as scholars bring alternative frames to understand resistance - frames that complicate the notion of resistance as a problem.

\section{THE IMPORTANCE OF QUESTIONING LARGE- SCALE PARTNERSHIP PROGRAMS}

More ways of perceiving, responding, and reframing the challenge of resistance will emerge as the appetite for partnership programs grows across the higher education sector. Contributing to the evolving conversation about resistance, I want to deliberately work against solutions to resistance which diminish the agency of students and faculty to decide about engaging for themselves. Perhaps my concern sounds extreme. But the seduction of 'success' in higher education should not be underestimated.

Let me share another example from my experience.

Several Australian universities have embraced student-faculty partnership with some allocating funding for large-scale programs at the institutional level. At one university, enthusiasm has translated into student partners being included in the redesign of large enrolment (500+ students) subjects into a blended (online and on-campus) format, in some cases without consulting the faculty involved. This resulted less from malicious intent and more from a rush to 'scale-up' quickly to meet KPls (key performance indicators for the program that outlined target numbers of students in a given year as defined in the implementation plan for the program). Regardless of intent, such approaches can be understood as a manifestation to include student partners in lots of 'partnership projects' to reach the 'measures of success' in ways that reduce perceived issues of resistance from non-student partners.

The unintended consequences of rushing to scale-up partnership programs could work against the fundamental ethos of 
engaging in pedagogical partnerships. Partnership should engender agency, amplify democratic principles, foster mutual respect for all involved as they share responsibility, and engage in a process of reciprocity. Where programs are focused on achieving specific outcomes with little attention to valuing student and faculty agency and autonomy to work together in ways that can transform notions power and identity (Matthews, 2017), then we should be asking questions. Such questioning should be received not as resistance, but rather as critical reflection expected when we take seriously our commitment to involve students as partners in learning and teaching.

\section{QUESTIONING THE LANGUAGE OF PARTNERSHIP}

Resistance to engaging with students as partners can arise from the actual words - students as partners - and how individuals will make sense of them. As a metaphor, the term 'students as partners' is not easily defined. For this reason, Healey et al (20I4) preferred to avoid a single definition, instead opting to offer a model for partnership in teaching and learning. A recent editorial in the International Journal for Students as Partners acknowledged the debate around the language of partnership related to students in teaching and learning, and concluded, "the practices of partnership will always be more complex than the words we use to describe them" (Cook-Sather et al, 2018, p. 6). In short, the language of students and partnership invites conversation. Thus, advocates for partnership practices should expect resistance and draw on questions to engage in a deeper sense-making process. Scholars, including myself, have argued that institutions adopting student partnership practices on a large scale need to develop their own language that supports both students and faculty in sharing an understanding of partnership (Cook-Sather, Bovill, \& Felten, 20I4; Matthews, 2016).

Engaging students as partners is an 'umbrella term' that encompasses a range of practices (Healey, Flint, \& Harrington, 20I4). For this reason, Bovill (20I7) outlined a framework to illuminate the type of partnership we are seeking to enact to ensure we are working intentionally toward partnership with students in learning and teaching. Thus, naming a program as a 'partnership program' when it is not undermines the creditable of partnership as a set of principles translated to practice. Moreover, mis-naming a partnership program also diminishes the value of including students in university-driven projects where they gain experience as interns or assistants working in traditional hierarchical university structures. Patterns of perceived resistance might actually be caused by claiming or naming a practice or program 'students as partners' when it is better labelled a student internship program, for example.

When we name a program intended to involve students in partnership, then we should be continuously asking questions about how we are supporting genuine partnership practices. If we see such questions as resistance, then we are closing the door on dialogue that can contribute to collective reflection and deeper engagement in partnership praxis. Indeed, by problematizing resistance that shuts down our questions about partnership practices and programs, we are resisting an opportunity for the type of learning that transforms our identities (Illeris, 2009). Furthermore, in framing questioning as resistance, we are opening the doors for the language of partnership to be co-opted. Co-opted for a business agenda that positions students as 'users' with faculty as 'service providers' in a higher education 'production line' while evoking the language of student partnership (see Dollinger, 2018). This is a form of appropriation where language becomes de-humanizing in a neoliberal ethic that works against engaging with students as learning partners for a more just and caring world (Cook-Sather \& Felten, 2017).

\section{QUESTIONING OURSELVES INSTEAD OF THOSE 'RESISTING PARTNERSHIP'}

What has become evident to me - through my recent experiences of translating policy into practice on a large-scale and my individual partnership practices - is that the ethic of partnership can easily get lost in translation. There are many reasons for this, which is a topic for another time [for discussion of partnership in neoliberal universities read Cook-Sather and Felten (2017) in the USA, Dwyer (2018) in Australia, and Wijaya Mulya (2018) in Indonesia]. Making sense of the resistance as a problem, the shifting discourse of thoughtful analysis of resistance, and my own observations have prompted this contribution - a piece asking us to keep questioning ourselves and our own motivations to engage others in partnership praxis.

Is our pre-occupation with the perceived challenge of resistance actually masking a more fundamental problem? A pre-occupation distracting us from the deeper, more extensive obstacle that undermines the commitment of the students as partners movement to the principles and values that define partnership? In our enthusiasm (and I mean our as I also reflect on my own motivations) to get more people doing students as partners, are we forgetting the principles of partnership? In doing so, are we actually contributing to the language of students as partners being co-opted because we are undermining the principles and values that define partnership as a practice?

My questioning of plans to 'scale-up' an institutional student partnership program at my university prompted a student partner to personally rebuke me by saying, 'you are always so critical'. Instead of my questions being an invitation to dialogue and think together as 'thinking friends', which Minnich (2017) recently argued is central to the 'close-in' human relationships that encourage everyday acts of goodness, they were perceived as resistance - as not being on board or supportive. In our busy and competitive university environments, slowing down to ask questions that allow those involved to share meaning and make sense together can feel burdensome when we feel the pressure to achieve and 'be successful' in a short timeframe. Yet engaging in such conversations is what defines partnership in learning and teaching.

I am guilty too.

Recently, I placed pressure on some partners to move us toward a tangible plan quickly. I tried to defer my responsibility in our shared decision-making process to them because I wanted to save time. Luckily, my partners questioned me, they called me out, in the spirit of partnership to remind me to value the messy process of the work. Instead of criticizing me or silently complying (which would have been understandable given my formal position of power relative to others in our university hierarchical structure), we engaged in dialogue and recognized the pressures working on us as students and faculty members in a competitive research-intensive university environment. We were engaging in the close-in human relational process that enables an independence of thought that welcomes us questioning each other in and through partnership (Matthews, 2018). A way of theorizing 
partnership that can transform how we think about resistance as a scholarly community.

When we frame resistance as an obstacle or barrier or challenge - instead of recognizing it as part of an organic sense-making process we have to question ourselves and each other in the spirit of partnership. Resistance is an opportunity to communicate (Bovill et al, 2016) and practice empathy (Ntem and CookSather, 2018). Resistance is an opportunity to think together: to question our beliefs about why our colleagues might be resisting the complex practice of pedagogical partnership and to reflect on our motivations as advocates for partnership when faced with perceived resistance from colleagues (be they students or faculty). Through such reflection, where resistance becomes an invitation to dialogue - to think together - we are living the principles of partnership that we want our colleagues to embrace when we advocate for 'students as partners in learning and teaching'.

\section{CONCLUSION}

I want to echo a colleague who commented in a 2016 pre-National Students as Partners Roundtable survey:

\begin{abstract}
I believe my own practices have reflected the "students as partners" philosophy, but I often encounter challenges with other staff, or students, who see the relationship more as an "us and them" situation. I would like to know how to encourage other staff in particular to see the value in the students as partners approach and also to be aware of the work involved in taking this approach.
\end{abstract}

I also want to support others in seeing the value while communicating the complexity of partnership work that challenges our taken for granted constructions of how learning and teaching happens in higher education. Genuinely portraying the emotional and intellectual commitment involved to both students and faculty that defines the messy process of partnership, I have come to learn, is fundamentally important. It is important because understanding and communicating the messy and relational praxis of partnership (Matthews et al, 2019) that is context-dependent (Healey \& Healey, 2018) and values-based (Cook-Sather, Bovill, \& Felten, 2014) has to inform plans to develop and 'scale-up' any formal partnership programs at the departmental, disciplinary, or institutional levels.

In doing so, we have to acknowledge what we are asking our colleagues to do. For some, the idea of engaging in partnership with students will come easily. Others, like me when I was first introduced to the language of 'students as partners', will have lots of questions. As advocates for partnership, we should welcome any questions - not as a form of resistance, but rather as a shared thinking process that brings new people into the partnership conversation as we think together about supporting, growing, and sustaining genuine partnership praxis.

\section{ACKNOWLEDGEMENTS}

Thank you to Mick Healey, Ruth Healey, and Sarah Rasmussen for offering their insights as critical friends that enriched this piece and my thinking.

\section{REFERENCES}

Bovill, C. (2017). A framework to explore roles within student-staff partnerships in higher education: Which students are partners, when, and in what ways?. International Journal for Students as Partners, I(I), I-5. https://doi.org/I0.15173/ ijsap.vlil.3062

Bovill, C., Cook-Sather, A., Felten, P., Millard, L., \& Moore-Cherry, N. (20l6). Addressing potential challenges in co-creating learning and teaching: Overcoming resistance, navigating institutional norms and ensuring inclusivity in student-staff partnerships. Higher Education, 7I(2), 195-20. https://doi. org/| 0.1007/s I0734-015-9896-4

Cates, R., Madigan, M. R., \& Reitenauer, V. (20I8). Locations of Possibility: Critical perspectives on partnership. International Journal for Students as Partners, 2(I), 33-46. https://doi. org/I0.15 I73/ijsap.v2il.334I

Cook-Sather,A., Bovill, C., \& Felten, P. (20I4). Engaging students as partners in learning and teaching:A guide for faculty. New York: John Wiley \& Sons.

Cook-Sather,A., \& Felten, P. (20 I7). Ethics of academic leadership: Guiding learning and teaching. In F. Su, \& M. Wood (Eds.), Cosmopolitan perspectives on academic leadership in higher education (pp. I75-19I). London: Bloomsbury Academic.

Cook-Sather,A., Matthews, K. E., Ntem,A., \& Leathwick, S. (20 I8). What we talk about when we talk about Students as Partners. International Journal for Students as Partners, 2(2), I-9. https://doi.org/I0.15I73/ijsap.v2i2.3790

Dollinger, M. (2017). Co-Creation in Higher Education. University of Melbourne: Doctoral dissertation. Retrieved from https://minerva-access.unimelb.edu.au/bitstream/handle/ I I343/2 I7993/Dollinger_thesis_fulltext I I.|4_acceptedchanges.pdf? sequence $=$ I \&isAllowed $=y$

Dwyer, A. (2018). Toward the formation of genuine partnership spaces. International Journal for Students as Partners, 2(I), I I15. https://doi.org/I0.I5173/ijsap.v2il.3503

Enright, E., Matthews, K.E., Russell, S., \& Sherwood, C. (20I8). National Students as Partners Roundtable Program. 4th Annual Australian National Students as Partners Roundtable, The University of Queensland, Brisbane, Australia, 2 October 2018. Brisbane, Australia: University of Queensland. Retrieved from https://espace.library.uq.edu.au/view/UQ:d$15 \mathrm{~d} 82 \mathrm{e}$

Felten, P. (20I3). Principles of good practice in SoTL. Teaching and Learning Inquiry, I(I), I2 I- I25. https://doi.org/ I0.20343/ teachlearninqu.I.I.I2I

Healey, M., Flint, A., \& Harrington, K. (20I4). Engagement through partnership: Students as partners learning and teaching in higher education. York: HE Academy. Retrieved from https:// www.heacademy.ac.uk/engagement-through-partnership-students-partners-learning-and-teaching-higher-education

Healey, M., \& Healey, R. L. (2018). 'It depends': Exploring the context-dependent nature of students as partners. International Journal for Students as Partners, 2(I), I-10. https://dx.doi. org/I0.15173/ijsap.v2il.3472

Illeris, K. (2018).A comprehensive understanding of human learning. In Knud Illeris (Ed) Contemporary Theories of Learning. (pp. I-I4). London: Routledge.

Kehler, A., Verwoord, R., \& Smith, H. (2017). We are the process: Reflections on the underestimation of power in students 
as partners in practice. International Journal for Students as Partners, I(I), I-I5. https://doi.org/I0.I5 I73/ijsap.v lil.3I76

Matthews, K.E. (20I8). Doing 'students as partners' is not enough: The role of theory in our partnership practices. In ISSoTL I 8 Toward a learning culture: Program and book of abstracts (p. 107). https://www.dropbox.com/s/n7rn6wgxeolpyy2/ISSOTLI8_program_book.pdf?dl=0

Matthews, K. E. (20I7). Five propositions for genuine students as partners practice. International Journal for Students as Partners, I(2), I-9. https://doi.org/I0.I5I73/ijsap.vli2.33I5

Matthews, K.E. (2016). Students as partners as the future of student engagement. Student Engagement in Higher Education Journal, I (I). Retrieved from https://journals.gre.ac.uk/index. $\mathrm{php} /$ raise/article/view/380

Matthews, K. E., Mercer-Mapstone, L., Dvorakova, S. L., Acia, A., Cook-Sather,A., Felten, P., Healey, M., Healey, R., \& Marquis, E. (20I8). Enhancing outcomes and reducing inhibitors to the engagement of students and staff in learning and teaching partnerships: Implications for academic development. International Journal for Academic Development. https://doi.org/I0. I080/I360 I44X.20I8.1545233

Matthews, K. E., Cook-Sather, A., Acai, A., Dvorakova, S. L., Felten, P., Marquis, E., \& Mercer-Mapstone, L. (2019). Toward theories of partnership praxis:An analysis of interpretive framing in literature on students as partners in university teaching and learning. Higher Education Research \& Development, 38(2), 280-293. https://doi.org/I0.1080/07294360.2018.1530199

Matthews, K. E., Dwyer, A., Hine, L., \& Turner, J. (20I8). Conceptions of students as partners. Higher Education, I-I 5. https:// doi.org/10.1007/s 10734-018-0257-y
Matthews, K. E., Dwyer, A., Russell, S., \& Enright, E. (20I8). It is a complicated thing: Leaders' conceptions of students as partners in the neoliberal university. Studies in Higher Education, 76(6), 957-97I. https://doi.org/I0.1080/03075079.20I8.I48 2268

Matthews, K.E, Cook-Sather, A., \& Healey, M. (20I8). Connecting learning, teaching, and research through student-staff partnerships: toward universities as egalitarian learning communities. In V.Tong, A. Standen, A., \& M. Sotiriou, (Eds.) Research Equals Teaching: Inspiring Research-Based Education through Student-Staff Partnerships. London: University College of London Press.

Minnich, E. (20I6). The evil of banality: On the life and death importance of thinking. New Jersey: Rowman \& Littlefield.

Ntem,A., \& Cook-Sather,A. (2018). Resistances and resiliencies in student-faculty pedagogical partnership. International Journal for Students as Partners, 2(I), 82-96. https://doi.org/ I 0.15173/ ijsap.v2il .3372

Peters, J., \& Mathias, L. (2018). Enacting student partnership as though we really mean it: Some Freirean principles for a pedagogy of partnership. International Journal for Students as Partners, 2(2), 53-70. https://doi.org// 0.I5I73/ijsap.v2i2.3509

Werder, C., Pope-Ruark, R., \& Verwoord, R. (2016). Students as Co-Inquirers (Special Section Guest Editors' Introduction). Teaching \& Learning Inquiry, 4(2), I-3. https://doi. org/l 0.20343/teachlearninqu.4.2.2

Wijaya Mulya, T. (2018). Contesting the neoliberalisation of higher education through student-faculty partnership. International Journal for Academic Development, I -5. https://doi.org/ I $0.1080 / 1360144 \times .2018 .1520110$ 